\title{
CORRELATION BETWEEN WORK LOAD AND WORK PERIOD WITH BLOOD PRESSURE AMONG WORKERS OF PT. $X$
}

\author{
Noeroel Widajati, Nur Laili Rizkiawati \\ Department of Occupational Safety and Health, Faculty of Public Health, Universitas Airlangga, Surabaya, Indonesia
}

\section{ABSTRACT}

\begin{abstract}
Industry that uses technology nowadays, beside having positive impacts, also having negative impacts such as adverse effects on workers and work environment. Every person who works will have workload and responsibility on their work. This will affect health of the workers, including their blood pressure. The purpose of this study was to study the relationship between work load and work period with blood pressure among workers in ship construction company, PT. X. This study was an observational descriptive study, using cross sectional design. Total population involved 41 individuals, taken from the respondents who met the inclusion criteria. Data collection included pulse and blood pressure measurements. Data analysis used in this study was Pearson and Spearman correlation tests. The result showed that there was a level of correlation between blood pressure and age (0.478), blood pressure and work period (0.432), blood pressure and work load (0.448). The conclusions of this study was that blood pressure related to age, nutritional status, work period, work load and noise intensity. PT X needs to pay attention to the health of the workers, such as blood pressure examination, and provide socialization on nutritious foods that are appropriate to the work performed.
\end{abstract}

Keywords: Work load; blood pressure

\section{ABSTRAK}

Penggunaan teknologi pada industri dewasa ini, selain berdampak positif, juga menimbulkan dampak negatif, seperti pengaruh buruk terhadap pekerja maupun lingkungan kerjanya. Setiap orang yang bekerja akan memiliki beban dan tanggung jawab pada pekerjaannya. Hal ini akan mempengaruhi kesehatan pekerja, salah satunya adalah gangguan tekanan darah. Tujuan dari penelitian ini adalah menentukan hubungan antara beban kerja dan masa kerja dengan tekanan darah pada pekerja bagian konstruksi kapal PT X. Penelitian ini merupakan penelitian observasional deskriptif, menggunakan desain penelitian cross sectional. Total populasi penelitian sebesar 41 orang dengan ketentuan responden memenuhi kriteria inklusi. Pengumpulan data meliputi pengukuran denyut nadi dan pengukuran tekanan darah. Analisis data yang digunakan dalam penelitian ini adalah korelasi Pearson dan Spearman. Hasil penelitian menunjukkan tingkat keeratan hubungan antara tekanan darah dengan usia (0,478), tekanan darah dengan masa kerja $(0,432)$ dan tekanan darah dengan beban kerja (0,448). Simpulan dari penelitian ini adalah tekanan darah berhubungan terhadap usia, masa kerja, dan beban kerja. PT X perlu memberikan perhatian terhadap kesehatan pekerja seperti pemeriksaan tekanan darah dan memberikan sosialisasi mengenai makanan yang bergizi sesuai dengan pekerjaan yang dilakukan.

Kata kunci: Beban kerja; tekanan darah

Correspondence: Noeroel Widajati, Department of Occupational Safety and Health, Universitas Airlangga, Surabaya, Indonesia.

pISSN:2355-8393 • eISSN: 2599-056x • doi: http://dx.doi.org/10.20473/fmi.v55i2.14340

- Fol Med Indones. 2019;55:117-121 • Received 6 Aug 2018 • Accepted 21 Feb 2019

- Open access under CC-BY-NC-SA license • Available at https://e-journal.unair.ac.id/FMI/

\section{INTRODUCTION}

In humans, the driving factor to work is the fulfillment of daily needs. According to the Central Bureau of Statistics, work is an economic activity undertaken by a person with the intention of obtaining or assisting in obtaining income or profits, carried out at least 1 hour (unbroken) within each week, including unpaid worker activity patterns that assist in an economic activity. The application of advanced science and technology to current industrial development is part of the industry's way to excel and directly improve productivity. Technology is intended for the implementation of work more efficiently, thus requiring workers or human resources who have expertise to master the technology.

Everyone who works will have a work load and responsibilities. Broadly speaking workload is divided into physical workload and mental workload. A physical workload or manual operation is a work with physical energy of the muscle or a fully the effort of the worker as the source of energy and control. As the body 
performs many activities, the heart pumps more blood. This means the number of heartbeats per unit of time increases. The heart rate frequency can be measured from the pulse. In a healthy heart, after being increased according to the demand of the work, the pulse will return to the level before work (Tarwaka, 2014).

The workload and the incidence of hypertension in labor has a significant relation. Based on the results of a study by Risky et al (2015), there was an increase in systolic and diastolic blood pressure after the workers performed their work. When a worker undergo an activity, there will be an increase in blood circulation to the organs of the body, increased heart rate and increased blood pressure due to strain on the muscles and increase in nerve. The amount of blood pressure can determine the work load itself. The increase of the load indicate the level of workload that affects the increase or the decrease in blood pressure (Tarwaka, 2004).

According to Blood Pressure Assosiation (2008), under normal circumstances, ideally a person's blood pressure is $120 / 80 \mathrm{mmHg}$. This can be found in individuals or workers who have a much lower risk of cardiovascular disease. Workers with high blood pressure (hypertension) show a level of $>140 / 90 \mathrm{mmHg}$ on measurement for several weeks. If the pressure is on the rise, there is pressure on the heart and blood vessels. Whereas low blood pressure (hypotension) measurements showed a level of $<90 / 60 \mathrm{mmHg}$. PT X has a compulsory gymnastics program every Friday morning that is intended as an effort toaintain the health of the workers, including their cardiovascular health. The purpose of this study was to analyze the relationship between workload and work period with blood pressure in workers at PT X.

\section{MATERIALS AND METHODS}

This was an observational descriptive research with cross sectional design. In this study, the population studied were workers who worked for 8 hours on ship construction and repair section in PT $X$. The construction section was chosen because the work system in the section had a target system where the task or work must be completed according to the agreement between PT X with its customers. If the specified limit is exceeded, the company will get a penalty. So, however, the worker must be able to complete on time, including working overtime which was often done, even within $>8$ hours or longer than working hours in general.

This study used a total sampling technique, due to the small number of populations and the time allowed for the researcher to conduct research on the entire population and because all the workers were male with the following inclusion criteria: age 20 years to 50 years, had no history of blood pressure disorders and obesity, have no alcoholic drinking habits, and meet the minimum category for light smokers. This research was conducted in May 2018 at PT X located in Surabaya.

Variables to be studied in this study included age, workload, work period, and blood pressure. Workload and blood pressure data were obtained through primary data by measuring heart rate or pulse using Brouha method and blood pressure using sphygmomanometer before and after the respondent worked (morning and afternoon). To reduce of the risk of error, the measurement was made twice five minutes after the first of each measurement and the average was taken. Blood pressure measurement was performed by someone who had the competence to perform the task. The variable of working period was obtained by secondary data by the researcher using direct interview to the respondents about the respondent's work period since first working in PT X. Data were analyzed using cross tabulation (Crosstabs). Data were presented as blood pressure measurement in correlation with workload and work period. Pearson Correlation statistical test was used to see the correlation between blood pressure and work period, while Spearman Correlation statistical test was used to see correlation between blood pressure change and work load.

\section{RESULTS}

The study respondents were total workers included in the inclusion criteria. We obtained 41 respondents who worked in the ship construction of PT X.

\section{Characteristics of respondents and work period}

Table 1. Distribution of age and working period of ship construction workers of PT X in May 2018

\begin{tabular}{lcc}
\hline \multirow{2}{*}{ Age (years) } & \multicolumn{2}{c}{ Total } \\
\cline { 2 - 3 } & $\mathrm{N}$ & $\%$ \\
\hline $21-30$ & 9 & 22 \\
$31-40$ & 15 & 36.5 \\
$41-50$ & 17 & 41.5 \\
\hline Total & 41 & 100 \\
\hline \multirow{2}{*}{ Work period (years) } & \multicolumn{2}{c}{ Total } \\
\cline { 2 - 3 } & $\mathrm{N}$ & $\%$ \\
\hline$\leq 10$ years & 17 & 41.5 \\
$11-20$ years & 7 & 17.1 \\
$21-30$ years & 17 & 41.5 \\
\hline Total & 41 & 100 \\
\hline
\end{tabular}


Table 1 shows that the age of the respondents was mostly $41-50$ years $(41.5 \%)$ and the least was $21-30$ years old $(22 \%)$. Based on work period, the least of the respondents has worked for $<10$ years, which was $41.5 \%$, in the range of $11-20$ years as much as $17.1 \%$, and range $21-30$ years as much as $39.5 \%$. Thus, most respondents have worked for 21-30 years.

\section{Workload}

Measurement of physical work load in this study used Brouha method, which was performed right after the workers finished their works. The results obtained as measured scores of P1, P2 and P3, which were then categorized under appropriate criteria. If P1-P3 > 10, or mean $\mathrm{P} 1,2,3<90$, the workers had normal recovery pulse. If the mean of $\mathrm{P} 1<110$ and $\mathrm{P} 1-\mathrm{P} 3>10$, the workload was not excessive. If P1-P3 $<10$ and if P3 > 90 , it was necessary to redesign the work.

Table 2. Distribution of the result of measurement of physical workload of the respondents

\begin{tabular}{llcc}
\hline No. & \multicolumn{1}{c}{ Criteria } & Total & $\begin{array}{c}\text { Percentage } \\
(\%)\end{array}$ \\
\hline 1. & Normal recovery pulse & 8 & 19.5 \\
2. & No excessive work load & 11 & 26.8 \\
3. & Need work redesigning & 22 & 53.7 \\
\hline & Total & 41 & 100 \\
\hline
\end{tabular}

The result of the measurement of physical workload on the respondents showed that $19.5 \%$ of the respondents had normal recovery pulse. Then, respondents with no excessive workload was as much as $26,8 \%$ and respondents who required work redesigning were as much as $53.7 \%$.

\section{Blood pressure}

Blood pressure measurement was done twice to reduce measurement error, then the average value was taken. Measurements were performed five minutes after the workers had actually, when they had actually rested or quit their activity so that a controlled blood pressure level would be obtained.

Table 3 shows that respondents who did not experience increased blood pressure or stable, by looking at differences in systole and diastole before and after work, were as many as 18 respondents with a percentage of $43.9 \%$. Respondents who experienced an increase in blood pressure were $56.1 \%$ or as many as 23 persons.

Table 3. Distribution of the result of measurement of blood pressure

\begin{tabular}{llll}
\hline No. & \multicolumn{1}{c}{$\begin{array}{c}\text { Result of } \\
\text { measurement }\end{array}$} & Total & Percentage (\%) \\
\hline 1. & No increase & 18 & 43.9 \\
2. & Increase & 23 & 56.1 \\
\hline & Total & 41 & 100 \\
\hline
\end{tabular}

\section{Analysis of correlation between age variables and blood pressure}

This analysis was conducted to determine the mapping of the number of each age range to the blood pressure of respondents in the ship construction section of PT X.

Table 4 shows that, out of 41 workers, the age range experienced the highest blood pressure increase at age 41-50 years or $34.1 \%$ and respondents who did not experience the highest blood pressure increase at 31-40 years old (19.5\%). Pearson Correlation test results showed the strength level of the relationship between age with blood pressure was 0.478 , included in moderate correlation category.

\section{Analyis of correlation between work period and blood pressure}

Cross-tabulation between work period and blood pressure is presented in Table 5.

Table 5 shows that of the 41 workers who experienced an increase in blood pressure, most of the respondents had worked for 21-30 years, as many as 13 persons. Respondents who did not experience the highest increase in blood pressure had work period of less than or equal to 10 years, as many as 12 respondents. The result of Pearson's Correlation test showed correlation value of 0.432 , indicating that the strength of correlation between the variable of working period and blood pressure belonged to moderate correlation.

Table 4. Cross-tabulation of age with blood pressure

\begin{tabular}{cccc}
\hline \multirow{2}{*}{ Age } & \multicolumn{2}{c}{ Blood pressure } & \multirow{2}{*}{ Total } \\
\cline { 2 - 3 } & No increase & Increase & \\
\hline $21-30$ & $7(17.1 \%)$ & $2(4.9 \%)$ & $9(22 \%)$ \\
$31-40$ & $8(19.5 \%)$ & $7(17.1 \%)$ & $15(36.6 \%)$ \\
$41-50$ & $3(7.3 \%)$ & $14(34.1 \%)$ & $17(41.4 \%)$ \\
\hline Total & $18(43.9 \%)$ & $23(56.1 \%)$ & $41(100 \%)$ \\
\hline
\end{tabular}


Table 5. Cross-tabulation on work period and blood pressure

\begin{tabular}{cccc}
\hline \multirow{2}{*}{ Work period } & \multicolumn{2}{c}{ Blood pressure } & \multirow{2}{*}{ Total } \\
\cline { 2 - 3 } & No increase & Increase & \\
\hline$\leq 10$ years & $12(29.3 \%)$ & $5(12.2 \%)$ & $17(41.5 \%)$ \\
$11-20$ years & $2(4.9 \%)$ & $5(12.2 \%)$ & $7(17.1 \%)$ \\
$21-30$ years & $4(9.7 \%)$ & $13(31.7 \%)$ & $17(41.4 \%)$ \\
\hline Total & $18(43.9 \%)$ & $23(56.1 \%)$ & $41(100 \%)$ \\
\hline
\end{tabular}

Table 6. Cross-tabulation of workload with blood pressure

\begin{tabular}{lccc}
\hline \multirow{2}{*}{ Work Load } & \multicolumn{2}{c}{ Blood Pressure } & \multirow{2}{*}{ Total } \\
\cline { 2 - 3 } & No increase & Increase & \\
\hline Normal recovery pulse & $6(14.6 \%)$ & $2(4.9 \%)$ & $8(19.5 \%)$ \\
No excessive work load & $7(17.1 \%)$ & $4(9.7 \%)$ & $11(26.8 \%)$ \\
Need work redesigning & $5(12.2 \%)$ & $17(41.5 \%)$ & $22(53.7 \%)$ \\
\hline Total & $18(43.9 \%)$ & $23(56.1 \%)$ & $41(100 \%)$ \\
\hline
\end{tabular}

\section{Analysis of correlation between work load and blood pressure}

Cross-tabulation between workload and blood pressure is shown in Table 6.

Table 6 shows that of the 41 workers, those who experienced an increase in blood pressure and included in the workload category that needed to redesign the work were the largest number, consisting of 17 people. Respondents working without increased blood pressure and included in the workload category that need to redesign the work of 5 people. The Pearson Correlation test results showed a correlation value of 0.448 , indicating the moderate relationship category.

\section{DISCUSSION}

\section{Physical work load of workers in ship construction section of PT X}

The construction part consists of sub-sections which work on manufacturing or assembling steel plates on ships or other materials such as iron and brass. Production starts from the design of the plate as required, the cutting of the plate, the assembly of the plate and the curvature of iron and brass required in the process of ship building.

While this study was being conducted, the respondents had just obtained a job to repair a ship with a short period of time, so there were some workers who had to work overtime a few days before. The impact of excessive workload will result in physical or mental fatigue or both and appear in the form of emotional reaction (Manuaba 2004).

\section{Correlation between age and blood pressure}

Most of human resource in the ship construction section were 41-50 years old. The section had not yet requested and had not opened new employee recruitment so the predominating ages were still 41-50 years. The strength of correlation between age and blood pressure level was 0.478 (moderate correlation). The results are in accordance with the theory of Bustan (1997) who found an increasing trend of prevalence by age, usually at age $>40$ years. This correlation exists because, along with increasing age, large arterial flexibility is reduced and becomes stiff. Therefore, the blood on each heartbeat is forced to pass through narrower blood vessels and leads to an increase in blood pressure (Sigarlaki 2006).

\section{Correlation between work period and blood pressure}

Most of the workers in the ship construction section of PT X had work period of 21-30 years. The average ages of the workers were 41-50 years so that the work period of those workers' work was long. The strength of correlation was 0.432 (moderate correlation). It indicates that the section has a comfortable working environment or there may be other factors that make the workers in PT X have long work period.

Such work period also affects workers' health due to exposure to hazards in the workplace environment. Hazardous environment in question is the behavior of some workers who are less maintaining their own health, such as smoking behavior. Some of the studied population were active smokers and passive smokers. The longer the worker is exposed to their own or someone else's smoke, the higher the risk of cardiovascular disease, one of which is blood pressure disorder (Beevers 2002). 


\section{Correlation between workload and blood pressure}

The strength of correlation indicates moderate correlation. The increase in blood pressure in some workers due to the influence of workload is evidenced by the increase in blood pressure found mostly in workers with workloads that required redesigning.

Blood pressure is a measure of the strength of blood suppressing the blood vessel walls. On the other hand, heartbeat is a count of how many times the heart pumps blood in one minute. Heart rate will increase when oxygen (contained in blood) demand in body tissues also increases. This correlation can occur because when the workers do the work activity, oxygen is often decreased, resulting in $\mathrm{O} 2$ deficiency in cardiovascular response due to supply from the lungs, or aerobically, insufficient. Then, oxygen is obtained from anaerobic metabolism (breakdown of ATP) in very limited amounts. The cardiovascular system reacts with the immediate supply of oxygen that has been borrowed from the blood. An example of this is the condition of breathless after carrying heavy loads. The heart accelerates its pulse to compensate for its inability to pump blood throughout the body. Significant increase in pulse rate is the result of a cardiovascular response to muscle contraction. This act also serves to transport the $\mathrm{O} 2$ needed by the muscles to perform contractions during the activities (Ganong 2003).

\section{CONCLUSION}

There is correlation between workload and blood pressure, as evidenced by the strength of correlation in moderate category. The correlation between the two variables is positive, which means that the higher the workload, the greater the disruption of blood pressure in the worker. There is a correlation between work period and blood pressure, as evidenced by the strength of correlation in moderate category. The correlation between the two variables is positive, which means that the longer a person's work period, the greater the disturbance of blood pressure, because it is also influenced by age, environmental factors, and behavior of the worker himself. PT X needs to pay attention to the health of the workers, such as regular blood pressure examination, as an effort to maintain the cardiovascular health of the workers and to provide socialization of nutritious foods in accordance with the work performed.

\section{REFERENCES}

American Heart Association (2016). The facts about high blood pressure. Available from http://www.heart.org/HEARTORG/Conditions/HighB loodPressure/GettheFactsAboutHighBloodPressure/Th e-Facts-About-High-Blood-

Pressure_UCM_002050_Article.jsp\#.WghouI-OPIU. Accessed July 16, 2018

Badan Pusat Statistik (2017). Available from https://www.bps.go.id/subjek/view/id/6. Accessed July, 162018

Beevers DG (2002). Seri kesehatan bimbingan dokter pada tekanan darah. Jakarta, Dian Rakyat

Bustan MN (1997). Epidemiologi penyakit tidak menular. Jakarta, Rineka Cipta

Ganong WF (2003). Review of medical physiology. 21th Ed. United States, The McGraw-HillCompanies Inc

Manuaba IBG (2004). Ilmu kebidanan, penyakit kandungan dan keluarga berencana untuk pendidikan bidan. Jakarta, EGC

Sigarlaki H (2006). Karakteristik dan faktor berhubungan dengan hipertensi di Desa Bocor, Kecamatan Bulus Pesantren, Kabupaten Kebumen, Jawa Tengah. Makara Kesehatan 10, 78-88

Sinubu, Risky Brian, et al (2015). Hubungan beban kerja dengan kejadian hipertensi pada tenaga pengajar di SMAN 1 Amurang Kabupaten Minahasa Selatan. eJournal Keperawatan (e-Kp) 3. Available from https://media.neliti.com/media/publications/105710ID-hubungan-beban-kerja-dengan-kejadian-hip.pdf. Accessed July 16, 2018

Tarwaka, Sholichul, Lilik S (2004). Ergonomi untuk keselamatan, kesehatan kerja dan produktivitas. Surakarta, UNIBA PRESS

Tarwaka (2014). Keselamatan dan kesehatan kerja: manajemen dan implementasi K3 di tempat kerja. Surakarta, Harapan Press 